\title{
Effects Deficit Irrigation and Mulching on Yield and Water Productivity of Furrow Irrigated Onion (Allium Cepa L.) Under Haramaya Condition, Eastern Ethiopia
}

\author{
Abdi Musa Sali ${ }^{1, a, *}$, Yibekal Alemayehu ${ }^{2, b}$, Tilahun Hordofa ${ }^{3, c}$ \\ ${ }^{1}$ Department of Irrigation and Watershed Management, Melkesa Agricultural Research Center, Ethiopia \\ ${ }^{2}$ Haramaya University, P.O.BOX 138, Dire Dewa, Ethiopia \\ ${ }^{3}$ Melkesa Agricultural Research Center, P.O.BOX, 436, Melkesa, Ethiopia \\ *Corresponding author
}

A R T I C L E I N F O

A B S T R A C T

Research Article

Received : 15/06/2021

Accepted : 05/12/2021

Keywords:

Water Application

Soil Sampling

Data Collection

Yield Response Factor

Total Bulb Yield

\begin{abstract}
In the background of improving Water Productivity, there is concern in deficit irrigation, which delivers a means of decreasing water depletion while reducing opposing effects on yield. A field experiment was conducted at Haramaya, Ethiopia during 2020 off-season. The objective was determining effects of irrigation levels and mulch types on yield and Water Productivity of Onion. The experimental design was a split plot in RCBD with three replications. The deficit irrigation levels $100 \%, 85 \%, 70 \%$ and $55 \%$ ETc used with the three mulch types no mulch, straw and white plastic mulch were used. The results revealed that the maximum yield of 38.43 ton ha-1 was recorded from $100 \%$ ETc with plastic mulch; whereas the minimum yield of 16.36 ton ha-1 was recorded from 55\% ETc with no mulch. Higher Crop Water Productivity of about $9.04 \mathrm{~kg}$ ha- $1 \mathrm{~mm}-$ 1 was obtained from $85 \%$ ETc with plastic mulch. With $85 \%$ ETc and plastic mulch the water saved, yield reduction and Crop Water Productivity were $113.13 \mathrm{~mm}, 9.57 \%$ and $9.04 \mathrm{~kg}$ ha- $1 \mathrm{~mm}-1$ respectively. In view of water saved and maximum yield, irrigation water application at $85 \%$ irrigation application levels and plastic mulch could be concerned. The current study recommends that, in water limited area, farming community can accept deficit irrigation level with $85 \%$ ETc under plastic mulch.
\end{abstract}

abdimus07@gmail.com (iD) https://orcid.org/0000-0002-4952-9509

tilahun_hordofa@yahoo.com (i) https://orcid.org/0000-0002-6757-6720 https://orcid.org/0000-0002-3095-3756

\section{(c) $($ ) (9) This work is licensed under Creative Commons Attribution 4.0 International License}

\section{Introduction}

In the background of improving water productivity, there is growing interest in deficit irrigation, a practice where by water supply is reduced below maximum level and mild stress is allowed with minimum effect on yield (Dirirsa et al., 2017 and Mekonen, 2011). Regulated deficit irrigation is water saving technology that is relatively inexpensive and easy to implement (Tilahun et al., 2004 and Temesgen et al., 2018). Under circumstances of water scarcity and drought, deficit irrigation can lead better water productivity by maximizing yield harvested per unit volume of water used (Temesgen et al., 2018). Onion (Allium cepa L.) is one of the most important vegetable crops in the world. It is the most widely cultivated species of the genus Allium and belongs to the family Alliaceae (Habtamu, 2017). Onion as food, medicine and religious object was known during the first Egyptian dynasty of 3200 BC (Ray and Yadav, 2005). Onion contributes nutritional value to the human diet and medicinal properties and is primarily consumed for their unique flavor or for their ability to enhance the flavor of other foods (Randle, 2000).

In Ethiopia, the crop is one of the most important vegetables produced by smallholder farmers mainly as a source of cash income and its bulb is used for flavoring the local stew 'wot' (Lemma and Shemelis, 2003). Onion crop was found to be sensitive to water stress during the whole growing season, therefore, it is better to partition the available water for the whole growing season to maintain moderate stress rather than creating a stress during the critical stages of plant growth (Kadayifci et al., 2004; Patel and Rajput, 2013). Onion crop is shallow rooted and susceptible to water stress (Rop et al., 2016). As result the crop is commonly given light and frequent irrigation.

The core limitations that contributed to lower productivity of onion in Ethiopia are type of cultivar, traditional and backward production methods and lack of proper irrigation methods, erratic rainfall, inadequate inputs, and many other problems (Awulachew et al., 2007 
and Nigatu, 2008). Understanding the yield response factor of onion with deficit irrigation all over the growing season is key for ideal scheduling of the limited water supply and for better crop management practice related to soil moisture. Hence, the study was introduced considering the existing problematic to determine the effects of deficit irrigation levels and mulches materials on yield and assess water productivity of onion under deficit irrigation levels, and mulch materials.

\section{Materials and Methods}

\section{Description of the Study Area}

The experiment was conducted at Haramaya University 'Rare' experimental site, Oromia, Ethiopia. The experimental site is located at about $530 \mathrm{~km}$ east of Addis Ababa, at an altitude of 2020 masl. It is located at $9^{\circ} 26^{\prime} \mathrm{N}$ latitude and $42^{\circ} 03^{\prime} \mathrm{E}$ longitude (Figure 1). The area has a sub humid climate with mean monthly minimum, maximum temperatures and average total annual rainfall of about $8.3^{\circ} \mathrm{C}, 25^{\circ} \mathrm{C}$ and $790 \mathrm{~mm}$ respectively.

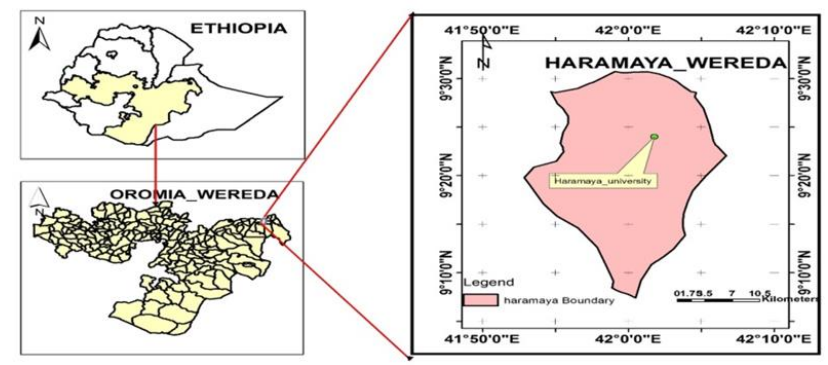

Figure 1. Location map of Haramaya University 'Rare' experimental site

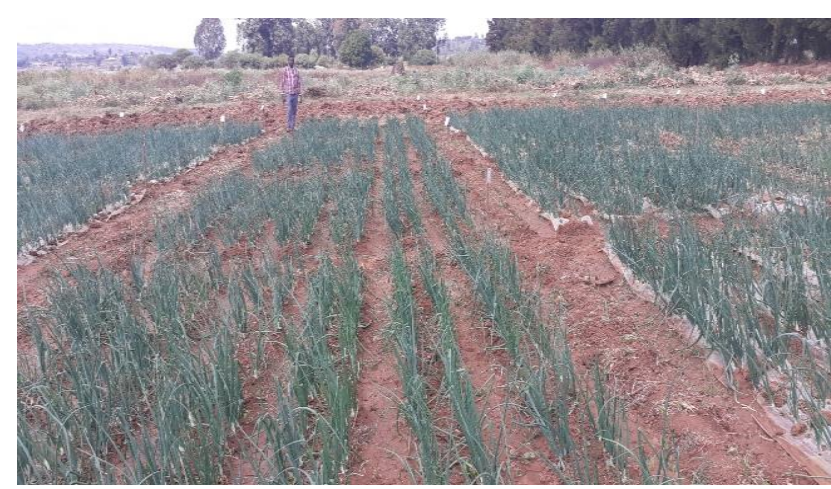

Figure 2. Pictures of No Mulch, Straw Mulch and White Plastic Mulch of Treatment plots under furrow irrigation.

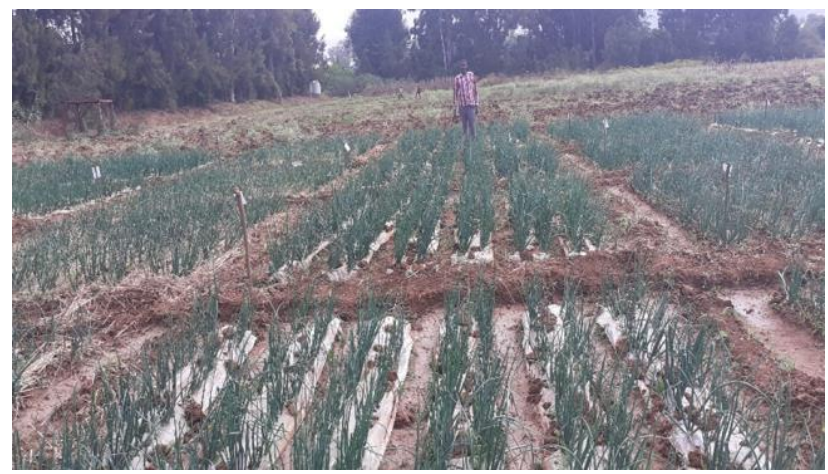

Figure 3. Soil moisture before and after irrigation.

\section{Experimental Design and Treatments}

The experimental design was in completely randomized block design with three replications. The Treatments include three deficit irrigation applications (85\% ETc, $70 \%$ ETc and 55\% ETc) and a full irrigation application (100\% ETc) and the three mulching material No Mulch (NM), Straw Mulch (SM) and Plastic Mulch (PM) figure 2. Contingent up on irrigation level value there is no standard value put but different researcher uses different values. The design of the level was corresponded with Heidari (2012) he used the same level of deficit for the same crop type. Control irrigation suggests the amount of irrigation water applied in accordance with the computed crop water requirement with the support of CROPWAT program.

\section{Experimental Techniques}

Seed Bed Preparation and Nursery Management

The ground for nursery bed was tilled and prepared to convey it to a well tilt and a seedbed was prepared. Nasik red onion variety called Melkesa Agricultural Research Centre was used for the study. The seeds were sown on nursery bed and the beds were enclosed with dry grass mulch until emergence and sprayed using a watering can. One-week earlier transferring, water supply to the nursery seedbed was minimized in order to strengthen the seedlings to reduce transplanting tremor. Formerly transplanting, the seedlings were watered to boost easy uprooting and to avert root damage.

\section{Experimental Plots Preparation}

The trial field plot was cultivated using tractor, smoothed and prepared by separating the field in to 36 plots for transplanting. The plot area was $4.2 \mathrm{~m} \mathrm{x} 4.0 \mathrm{~m}=16.8$ $\mathrm{m}^{2}$, with $1 \mathrm{~m}$ spacing between adjacent plot and $1.5 \mathrm{~m}$ between replications. A plot comprised of six ridges/furrow/ with two rows per ridges with a row length of $4.0 \mathrm{~m}$. The seedlings were transferred to field plots on the first week of December 2019. Transplanting was done late in the afternoon to reduce the risk of poor establishment. More number of seedlings than that required for transplanting was raised so that vigorous, strong and healthy ones were selected. The spacing between plants within a row and between rows were $10 \mathrm{~cm}$ and $20 \mathrm{~cm}$, respectively, with 12 rows per plot. A row consists of 40 plants and a plot 480 plants. The net harvesting area of a plot was $3.8 \mathrm{~m}$ by $3.6 \mathrm{~m}(13.68 \mathrm{~m} 2)$. The first plant was planted $20 \mathrm{~cm}$ from the border row in each plot.

\section{Irrigation Water Application}

Irrigation water applied to each experimental plot was measured using 2-inch Parshall flume and installed $10 \mathrm{~m}$ away from the nearest plot along main canal. Calculated gross irrigation was finally applied to each experimental plot based on the treatments proportion. Volume of water applied for every treatment was determined from plot area and depth of gross irrigation requirement. Time required to irrigate each treatment was calculated from the ratio of volume of applied water to the discharge-head relation of 2-inch Parshall flume. The time required to deliver the desired depth of water into each furrow was calculated using equation given by Michael (2008). 


$$
\mathrm{T}=\frac{\mathrm{A} \times \mathrm{d}}{6 \times \mathrm{q}}
$$

Where;
d: Is gross irrigation depth of water to be applied (cm)
A: Is Area of the experimental plot $\left(\mathrm{m}^{2}\right)$
$\mathrm{T}$ : Is application time (min)
Q: Is flow rate of discharge $(1 / \mathrm{s})$.

Simple irrigations were given preceding to commence of treatments applications for thirteen days. Water applications for full irrigation treatments $(100 \%$ ETc) were based on the estimated crop water requirement calculated over the growing period and those water deficit treatments $85 \%, 70 \%$ and $55 \%$ ETc were imposed as planned. Irrigation frequencies were calculated based on daily climatic data under furrow irrigation in the whole growing season. The prearranged amount of irrigation water was based on allowable soil moisture depletion for onion $(\mathrm{p}=$ 0.30). Soil moisture was monitored before and after irrigation using gravimetric method. Irrigation interval and depth of irrigation was determined based on allowable soil moisture depletion. The depths of water applied to the field and the soil moisture content before each irrigation events were assumed to be equal to the prescribed irrigation treatment. Irrigation scheduling was determined based on soil moisture monitoring using gravimetric method. Based on regular soil moisture observation, irrigation was applied to onion crop through furrow when about $30 \%$ of available soil moisture was depleted from the effective root zone. The root depth of onion can extend up to $1 \mathrm{~m}$ but under irrigation, roots are concentrated mainly in the upper $30 \mathrm{~cm}$ soil depth. Nevertheless, $100 \%$ of the water uptake occurs in the first 0.3 to $0.5 \mathrm{~m}$ soil depth $(\mathrm{drz}=0.3-0.5 \mathrm{~m})$. In this study, the maximum crop root depth was considered as $1.0 \mathrm{~m}$. Soil moisture was monitored during experimental time up to 50 $\mathrm{cm}$ by considering the growth stage of onion. Prior to irrigation, available soil moisture content for all the treatments were measured at 0-15, 15-30, 30-45 and 45-60 $\mathrm{cm}$ soil depths using the gravimetric method. The total depth of water was applied to 1.0 ETc to bring the measured gravimetric soil water content to field capacity level and to other stressed treatment to bring the measured gravimetric soil water content to prescribed soil water after irrigation.

Table 1. Treatment combinations

\begin{tabular}{l|ccc}
\hline Main plot & Sub plot & Description & Code \\
\hline & Irrigated at 100\% ETc & Irrigated at 100\% ETc, no mulch & T1 \\
No Mulch & Irrigated at 85\% ETc & Irrigated at 85\% ETc, no mulch & T2 \\
& Irrigated at 70\% ETc & Irrigated at 70\% ETc, no mulch & T3 \\
& Irrigated at 55\% ETc & Irrigated at 55\% ETc, no mulch & T4 \\
\hline & Irrigated at 100\% ETc & Irrigated at 100\% ETc, plastic mulch & T5 \\
& Irrigated at 85\% ETc & Irrigated at 85\% ETc, plastic mulch & T6 \\
& Irrigated at 70\% ETc & Irrigated at 70\% ETc, plastic mulch & T7 \\
& Irrigated at 55\% ETc & Irrigated at 55\% ETc, plastic mulch & T8 \\
\hline & Irrigated at 100\% ETc & Irrigated at 100\% ETc, straw mulch & T9 \\
& Irrigated at 85\% ETc & Irrigated at 85\% ETc, straw mulch & T10 \\
& Irrigated at 70\% ETc & Irrigated at 70\% ETc, straw mulch & T11 \\
& Irrigated at 55\% ETc & Irrigated at 55\% ETc, straw mulch & T12 \\
\hline
\end{tabular}

Table 2. Physical properties of the experimental soil

\begin{tabular}{|c|c|c|c|c|c|c|}
\hline \multirow{2}{*}{\multicolumn{2}{|c|}{ Soil physical property }} & \multicolumn{5}{|c|}{ Soil depth in $(\mathrm{cm})$} \\
\hline & & $(0-15)$ & $(15-30)$ & $(30-45)$ & $(45-60)$ & Average \\
\hline \multirow{3}{*}{ Particle size Distribution } & Sand $(\%)$ & 67 & 56 & 66 & 68 & 64.25 \\
\hline & Silt $(\%)$ & 17 & 20 & 17 & 14 & 17.00 \\
\hline & Clay $(\%)$ & 16 & 24 & 17 & 18 & 18.75 \\
\hline \multicolumn{2}{|l|}{ Textural class } & Sandy loam & Sandy clay loam & Sandy loam & Sandy loam & Sandy loam \\
\hline \multicolumn{2}{|l|}{ Bulk density $\left(\mathrm{g} / \mathrm{cm}^{3}\right)$} & 1.40 & 1.41 & 1.56 & 1.49 & 1.48 \\
\hline \multicolumn{2}{|c|}{ Field capacity (\%) (mass basis) } & 27.76 & 27.00 & 23.77 & 27.96 & 26.62 \\
\hline \multicolumn{2}{|c|}{ Permanent wilting point (\%) (mass basis) } & 14.10 & 16.85 & 15.10 & 15.37 & 15.35 \\
\hline \multicolumn{2}{|c|}{ Total available water $(\mathrm{mm} / \mathrm{m})$} & 193.69 & 144.03 & 132.74 & 187.65 & 165.67 \\
\hline
\end{tabular}

Table 3. Interaction effects of irrigation levels and mulch techniques on marketable and unmarketable bulb yields of onion

\begin{tabular}{|c|c|c|c|c|c|c|}
\hline \multirow{3}{*}{ Irrigation levels } & \multicolumn{3}{|c|}{ Marketable bulb yield (t/ha) } & \multicolumn{3}{|c|}{ Unmarketable bulb yield (t/ha) } \\
\hline & \multicolumn{3}{|c|}{ Mulch types } & \multicolumn{3}{|c|}{ Mulch types } \\
\hline & NM & SM & PM & NM & SM & PM \\
\hline $100 \%$ ETc & $26.26^{\mathrm{d}}$ & $31.40^{\mathrm{b}}$ & $34.27^{\mathrm{a}}$ & $3.53^{\mathrm{b}}$ & $3.73^{b}$ & $4.16^{\mathrm{a}}$ \\
\hline $85 \%$ ETc & $23.19^{f}$ & $29.62^{c}$ & $31.16^{\mathrm{b}}$ & $3.00^{\mathrm{c}}$ & $3.20^{\mathrm{c}}$ & $3.60^{\mathrm{b}}$ \\
\hline $70 \%$ ETc & $21.54^{\mathrm{g}}$ & $25.82^{\mathrm{e}}$ & $26.35^{\mathrm{d}}$ & $2.53^{\mathrm{d}}$ & $2.50^{\mathrm{d}}$ & $2.40^{\mathrm{d}}$ \\
\hline $55 \%$ ETc & $14.79^{\mathrm{j}}$ & $18.09^{\mathrm{i}}$ & $19.47^{\mathrm{h}}$ & $1.56^{\mathrm{e}}$ & $2.30^{\mathrm{d}}$ & $2.30^{\mathrm{d}}$ \\
\hline $\operatorname{LSD}(5 \%)$ & \multicolumn{3}{|c|}{0.42} & \multicolumn{3}{|c|}{0.30} \\
\hline $\mathrm{CV}(\%)$ & \multicolumn{3}{|c|}{0.75} & \multicolumn{3}{|c|}{5.87} \\
\hline
\end{tabular}

Means of a variable followed by the same letter are not significantly different at 5\% level of significance. 


\section{Soil Sampling and Analysis}

The soil samples were taken from top soil to the depth of $60 \mathrm{~cm}$ in $15 \mathrm{~cm}$ interval. The sub-samples were mixed thoroughly, dried at room temperature, ground and sieved through a $2 \mathrm{~mm}$ screen for physical and chemical analysis; whereas for $\mathrm{OC}$ and total $\mathrm{N}$ determination soil samples were passed through $0.5 \mathrm{~mm}$ sieve. Soil textural analysis was done using disturbed soil samples that were collected from representative location of the field and textural class was determined by using pipette method in laboratory.

The bulk density was determined using undisturbed soil samples that were collected from the field at three depths $(0-15 \mathrm{~cm}, 15-30 \mathrm{~cm}, 30-45 \mathrm{~cm}$ and $45-60 \mathrm{~cm})$ oven dried for $24 \mathrm{hrs}$ at $105{ }^{\circ} \mathrm{C}$ and weighed for determination of dry mass. The bulk density was calculated as (Michael, 2008)

$$
\mathrm{BD}=\frac{\mathrm{Ms}}{\mathrm{Vt}}
$$

Where;

BD: Is bulk density $\left(\mathrm{g} / \mathrm{cm}^{3}\right)$

Ms: Is dry mass of the soil $(\mathrm{g})$

Vt: Is total volume of the soil $\left(\mathrm{cm}^{3}\right)$.

Determination soil moisture is important of monitoring irrigation. Soil moisture at field capacity (FC) and permanent wilting point (PWP) were determined. For this, the soil samples were collected the four depths described above and sun dried, crushed then, soaked in water for one day $(24 \mathrm{hr})$. Pressure plate apparatus and pressure membrane apparatus were used for determination of moisture content at FC and PWP. A suction of $-1 / 3$ bar and -15 bar were exerted for FC and PWP, respectively, for this purpose.

Total available water (TAW) is described by (Allen et al., 1998).

$$
\mathrm{TAW}=1000\left({ }^{\Theta}{ }_{\mathrm{FC}}-{ }^{\Theta}{ }_{\mathrm{PWP}}\right) \mathrm{p}_{\mathrm{b}} \times \mathrm{Z}_{\mathrm{r}}
$$

Where;

TAW: $\quad$ Is the total available soil water content (mm) $\theta F C$ : $\quad$ Is soil moisture content at field capacity $(\mathrm{cm} 3 / \mathrm{cm} 3)$

$\theta$ PWP: Is soil moisture content at field permanent wilting point $\left(\mathrm{cm}^{3} / \mathrm{cm}^{3}\right)$

$\mathrm{pb}$ : $\quad$ Is the bulk density of the soil in $\mathrm{gm} / \mathrm{cm}^{3}$

$\mathrm{Zr}$ : $\quad$ Is crop rooting depth $(\mathrm{m})$ to which TAW is to be calculated.

\section{Water Productivity}

Crop water productivity (WP) simply refers to the output (example, crop yield or economic return) with respect to water input during production. This mean the output may be expressed either as physical production in kilograms per unit area or economic return in dollars per area. The water input is the amount of water applied to the cropped area per season. In this study crop, water productivity was assessed as the ration of onion bulb yield to net irrigation depth applied to each treatment plot. It is expressed by (Zwart and Bastiaanssen, 2004).

$$
\mathrm{WP}=\frac{\mathrm{Yc}}{\mathrm{ETc}}
$$

Where;

WP: Is crop water productivity $\left(\mathrm{kg} / \mathrm{m}^{3}\right)$

Yc: Is crop yield ( $\mathrm{kg} / \mathrm{ha})$

ETc: Is the seasonal crop water consumption $\left(\mathrm{m}^{3} / \mathrm{ha}\right)$.

\section{Crop Data Collection}

The Crop data was collected from the middle rows in order to avoid border effects. The plants were picked at random carefully from middle three rows by avoiding one plant from starting and ending of three middle rows. Data regarding different components of growth yield and yield components were recorded. These data include among others:

Plant Height $(\mathrm{Cm})$

Plant heights of ten randomly selected plants were measured from the soil surface to the top of the longest leaf using a ruler at physiological maturity. Mean value of the ten-plant height was recorded as plant height of each plots.

Leaf Height $(\mathrm{Cm})$

The longest leaves of ten randomly selected plants at physiological maturity were measured from the point of their emergence-using ruler and were expressed as a mean value in centimeter $(\mathrm{cm})$.

Weight of Bulb (Single Onion Bulb Weighed)

The mean of weights of the bulb for each onion bulb taken randomly from plot.

Marketable Yield $(\mathrm{Kg} / \mathrm{Ha})$

Is in decent physical shape and non-diseased average to huge sized Nasik Red onion bulbs were recorded from central four harvestable ridges.

Unmarketable Onion $(\mathrm{Kg} / \mathrm{Ha})$

Is riven, decomposed, diseased and below sized bulbs.

Total Bulb Yield $(\mathrm{Kg} / \mathrm{Ha})$

Is the sum of marketable and unmarketable bulb yields.

Total Biomass Yield $(\mathrm{Kg} / \mathrm{Ha})$

This was determined by summation of all above and underground biomass weights of sample plants.

Yield Response Factor

In order to quantify the effect of water deficit on onion, the empirically derived yield response factor (ky) was used and it is the relative yield decrease to relative evapotranspiration deficit using the following equation by (Singh et al., 2010).

$$
\left(1-\frac{\mathrm{Ya}}{\mathrm{Ym}}\right)=\mathrm{Ky}(1-\mathrm{ETa} / \mathrm{ETm}
$$

Where;

Ym and Ya: Are the maximum and actual yields (kg/ha)

ETm and Eta: Are the maximum and actual evapotranspiration $(\mathrm{mm})$ and $\mathrm{Ky}$ is a yield response factor.

\section{Data Analysis}

All necessary data collected were managed properly using SAS computer package version 9.1. When the treatments effect was found significant, mean difference was tested using LSD test at $\mathrm{P}=0.05$. 
Table 4. Interaction effects of irrigation levels and mulch types on total bulb yield of onion (ton ha-1)

\begin{tabular}{l|ccc}
\hline \multirow{2}{*}{\multicolumn{1}{c}{ Irrigation levels }} & \multicolumn{3}{c}{ Total bulb yield } \\
\cline { 2 - 4 } $100 \%$ ETc & NM & SM & PM \\
$85 \%$ ETc & $29.78^{\mathrm{d}}$ & $35.13^{\mathrm{b}}$ & $38.43^{\mathrm{a}}$ \\
$70 \% \mathrm{ETc}$ & $26.19^{\mathrm{f}}$ & $32.82^{\mathrm{c}}$ & $34.76^{\mathrm{b}}$ \\
$55 \% \mathrm{ETc}$ & $24.07^{\mathrm{g}}$ & $28.32^{\mathrm{e}}$ & $28.75^{\mathrm{e}}$ \\
\hline LSD $(0.05)$ & $16.36^{\mathrm{i}}$ & $20.39^{\mathrm{i}}$ & $21.77^{\mathrm{h}}$ \\
CV $(\%)$ & & 0.45 & \\
\hline ME & & 0.85 & \\
\hline
\end{tabular}

Means followed by the same letter are not significantly different at $5 \%$ level of significance.

Table 5. Relative yield reduction of onion and water saved

\begin{tabular}{l|ccccccc}
\hline Trts & TBY (t/ha) & I gross $\left(\mathrm{m}^{3} / \mathrm{ha}\right)$ & WS $\left(\mathrm{m}^{3} / \mathrm{ha}\right)$ & WS $(\%)$ & Yield Reduction $(\%)$ & Additional land (ha) & Additional yield (t/ha) \\
T1 & 29.78 & 7542.00 & 0.00 & 0.00 & 0.00 & 0.00 & 0.0 \\
T2 & 26.19 & 6410.70 & 1131.30 & 15 & 12.06 & 0.18 & 4.6 \\
T3 & 24.07 & 5279.40 & 2262.60 & 30 & 19.17 & 0.43 & 0.3 \\
T4 & 16.36 & 4148.10 & 3393.90 & 45 & 45.07 & 0.82 & 13.4 \\
T5 & 38.44 & 7542.00 & 0.00 & 0.00 & 0.00 & 0.18 & 0.0 \\
T6 & 34.76 & 6410.70 & 1131.30 & 15 & 9.57 & 0.43 & 0.1 \\
T7 & 28.75 & 5279.40 & 2262.60 & 30 & 25.19 & 0.82 & 12.3 \\
T8 & 21.77 & 4148.10 & 3393.90 & 45 & 43.35 & 0.00 & 17.8 \\
T9 & 35.13 & 7542.00 & 0.00 & 0.00 & 0.00 & 0.18 & 0.0 \\
T10 & 32.82 & 6410.70 & 1131.30 & 15 & 6.58 & 0.43 & 5.8 \\
T11 & 28.32 & 5279.40 & 2262.60 & 30 & 19.39 & 0.82 & 12.1 \\
T12 & 20.39 & 4148.10 & 3393.90 & 45 & 41.96 & & 16.7 \\
\hline
\end{tabular}

Trts=treatments, TBY= total bulb yield, $\mathrm{WS}=$ saved water and I gross=gross irrigation

Table 6. Interaction effect of irrigation levels and mulch types on onion water productivity $\left(\mathrm{kg} / \mathrm{m}^{3}\right)$

\begin{tabular}{l|ccc}
\hline \multirow{2}{*}{ Irrigation levels } & \multicolumn{3}{c}{ Water productivity } \\
\cline { 2 - 4 } $100 \%$ ETc & $\mathrm{NM}$ & SM & PM \\
$85 \%$ ETc & $6.58^{\mathrm{k}}$ & $7.76^{\mathrm{h}}$ & $8.49^{\mathrm{f}}$ \\
$70 \%$ ETc & $6.81^{\mathrm{j}}$ & $8.53^{\mathrm{e}}$ & $9.04^{\mathrm{b}}$ \\
$55 \% \mathrm{ETc}$ & $7.60^{\mathrm{i}}$ & $8.94^{\mathrm{c}}$ & $9.06^{\mathrm{a}}$ \\
\hline LSD $(0.05)$ & $6.57^{\mathrm{k}}$ & $8.19^{\mathrm{g}}$ & $8.75^{\mathrm{d}}$ \\
CV $(\%)$ & & 0.018 & \\
\hline
\end{tabular}

Means followed by the same letter are not significantly different at $5 \%$ level of significance. NM = No mulch, SM = Straw mulch, WPM = Plastic mulch (white)

\section{Results and Discussion}

\section{Irrigation Water Application}

The quantity of water applied was based on the daily reference evapotranspiration for the study. The daily reference evapotranspiration was calculated using the FAO-Penman-Monteith method. Soil moisture contents were monitored prior and after irrigation using the gravimetric method from the plots of the all replication (block) throughout the growing season and then these values were converted to volumetric water contents using bulk density. The crop water requirement (ETc) of onion crop was calculated by multiplying the reference evapotranspiration (ETo) with crop coefficient (Kc). The gravimetric soil moisture content revealed that the net total irrigation water determined in $\mathrm{mm}$ for each treatment (100\% ETc, $85 \%$ ETc, $70 \%$ ETc and $55 \%$ ETc) were through furrow irrigation methods at the entire growing period of the crop as it was determined from multiplication of total available water (TAW) and depletion fraction $(p=0.30)$. The gravimetric soil moisture also shown that the total gross irrigation water applied in $\mathrm{mm}$ to each treatment from (100\% ETc, $80 \%$ ETc, $70 \%$ ETc and $55 \%$ ETc) discussed. The total gross depths of irrigation water applied in mm through furrow irrigation methods were varied. The application efficiency of furrow irrigation method is taken as $60 \%$ and crop water requirement is taken in $\mathrm{mm} /$ period.

\section{Yields and Yield Related Constituents \\ Marketable Bulb Yield}

Interaction effect of deficit irrigation levels through mulching types revealed a highly significant $(\mathrm{P}<0.01)$ influence on the marketable yield. The highest marketable yield (34.27-ton ha-1) was attained from joint application of treatment received $100 \%$ ETc and plastic mulch while the lowest marketable yield (14.79-ton ha-1) was attained from treatment received 55\% ETc and no mulch. However, there was significant difference observed in marketable yield between plots treated by 55\% ETc Plastic and straw mulch treatments. For each mulching types, marketable yield was diminished with increase in irrigation deficit levels. The tendency tended to suggest marketable yield was significantly higher as the soil moisture stress decreases. This could be due to the difference in depth of irrigation water applied. The increment of marketable yield 
as the amount of irrigation levels increased is similar with the (Temesgen et al., 2018) which indicated that yield reduction was associated with increase in soil moisture tension which when allowed continuing resulted in loss of turgidity, cessation of growth and yield reduction.

In other words, favorable environment for growth of onion plants maintained by application of plastic mulch followed by plots treated with straw mulch than no mulch along with the increased irrigation levels may have contributed to the production of highest marketable yield. The present finding is in agreement with the results of (Chawla, 2006)) who reported that the highest marketable yield was obtained through black plastic mulch followed by straw mulch (50.02 tons/ha) in tomato crop.

\section{Unmarketable Bulb Yield}

The analysis of variance showed that interaction effect of deficit irrigation levels and mulching types resulted significant $(\mathrm{P}<0.05)$ effect on this parameter. The highest unmarketable yield was noted from plants grown under $100 \%$ and plastic mulch which was about (4.16-ton ha-1), followed by the treatment that received $100 \%$ ETc and straw mulch. The highest unmarketable yield was recorded from plot that received plastic mulch followed by straw mulch under increased water application levels. The lowest unmarketable dry bulb yield was recorded from plants without mulch. This finding is in line with (Tasisa et al., 2018) who reported that the highest unmarketable onion yield was obtained from plastic mulch followed by straw mulch under increased water application levels.

\section{Total Bulb Yield}

Analysis of variance showed that total yield of Nasik Red onion variety was highly significant $(\mathrm{P}<0.01)$ influenced by the interaction effect of deficit irrigation levels and mulching types. Accordingly, the maximum total yield (48.43-ton ha-1) was obtained from the treatment that received $100 \%$ ETc and plastic mulch, followed by plants that grown mulched with $100 \%$ ETc and straw mulch. The minimum total yields (16.36-ton ha-1) were recorded at the treatment combination of $55 \%$ ETc and no mulch. High total bulb yield was obtained from high depth of water applied $100 \%$ ETc under plastic, straw and no mulch respectively and this was significantly different from relatively low depth of water applied treatments 85 , 70 and 55\% ETc under plastic, straw and no mulch respectively (Table 4$)$.

For each deficit irrigation level, maximum total yield was obtained from plots treated with plastic mulch, which was followed, by plots treated with straw mulch than that was obtained from control (no mulch). Consequently, for each mulching types, total yield decreased with increase in the irrigation level deficit. Therefore, yield decrease observed in the treatments that received less depth of water per season might be a result of floral abortion, flower drop, immature bulb drops and reduction in bulb number per plant and (Bosland and Votava, 2000 and Tasisa, 2018) report consequently total yield reduction due to water stress. The observed marked reduction in total bulb yields due to irrigating at 0.55 ETc confirmed the sensitivity of the onion to water stress. Likewise, high floral abortion was observed due to deficit irrigation and partial root drying treatments in an experiment carried out by (Bosland and Votava, 2000) showing the mechanism of bulb yield reduction due to water stress. The significant difference observed between deficit irrigation levels and mulching on total yield of onion in the current study is, therefore, a reflection of the variation in depth of water applied in the respective deficit irrigation levels. The general trend from this result observed that the yield of onion in-creased with high depth of water supply and decreased with low depth of water supply under different mulching techniques.

\section{Yield and Irrigation Water Levels Relationship}

The relationship between yield (ton ha-1) and the depth of irrigation water under different mulch types is presented in Table 4. The average yield in study area under deficit irrigation is about 38.43-ton ha-1. One should notice that treatment received 55\% ETc and no mulch that received $248.8 \mathrm{~mm}$ irrigation water throughout the growing season produced 16.36-ton ha-1. Full irrigation (100\% ETc under plastic mulch), was used as the reference point for calculation yield, water saved and relative yield decrease relationship under distinct deficit irrigation levels and mulch types. The data showed that the highest yield reduction $(45.07 \%$ ) was observed under treatment received $55 \%$ ETc and no mulch while, lowest yield reduction is observed under treatment received 85\% ETc and straw mulch. Treatment 55\% ETc under plastic, straw and no mulch had shown the highest yield reduction as compared to the other treatments under plastic, straw and no mulch resulted in respectively.

From this result, it can be perceived that the yield reduction is lower if the crop is 15 and 30\% deficit rather than $45 \%$ deficit under different mulching types for the crop throughout the growing season. Similarly, (Smith, 2011) was reported that $34 \%$ less water supply resulted in onion yield reduction of $42 \%$ and $20 \%$ less water resulted in yield reduction of $27 \%$ when compared with system that was fully irrigated. In an irrigation experiment with onion in New Mexico, the application of $20 \%$ less water than the full supply reduced the bulb yields by about $10 \%$ (Nigatu, 2008).

From the result, it can be observed that the yield reduction in treatment received 70 and $85 \%$ ETc under plastic mulch is lower as compared to amount of water saved than the other treatments (Table 4). However, applying 55\% ETc of water under plastic, straw and no mulch significantly reduced the yield. The yield reduction is proportional to the decrease for water applied under different mulch types. For example, applying irrigation water $70 \%$ ETc under plastic mulch throughout the whole growing season of onion reduced the yield $25.19 \%$ while water saved $113.13 \mathrm{~mm}$ relative to control treatment. The yield obtained reliably decreased with the decrease for water applied excepting for 70 and $85 \%$ ETc under plastic and straw mulch respectively. Under field conditions, inadequate water supply can unfavorably affect growth and yield of onion in treatment $55 \%$ ETc than the full irrigation. It was stated that onion was too sensitive to moisture stress and reduced yield significantly at $50 \%$ of water supply (Temesgen et al., 2018 and Dirirsa et al., 2017).

\section{Crop Water Productivity}

Crop water productivity of the onion was highly significantly $(\mathrm{P}<0.01)$ affected by the interaction effects of deficit irrigation levels and mulch types. The interaction of deficit irrigation and mulch types showed there were highly 
significant differences in productivity values when tested at the $5 \%$ level. Under $85 \%$ irrigation water application and plastic mulch, the highest Crop water productivity of $(9.08$ $\mathrm{kg}$ ha-1 mm-1) were obtained. The lowest crop water productivity $(6.57 \mathrm{~kg}$ ha-1 $\mathrm{mm}-1)$ was obtained from $55 \%$ irrigation water deficit and no mulch (Table 6). These results show the positive effect of mulch covers even with deficit levels up to $55 \%$ ETc bare soil (no mulch) was not efficient in conserving water.

Crop water productivity was increasing in the same water application level under the mulching order of no mulch, straw and plastic mulch respectively. Hence, maximum crop water productivity was recorded from treatment $85 \%$ ETc and plastic mulch (9.08-ton ha-1 mm1) followed by $70 \%$ ETc plastic $(9.06 \mathrm{~kg} \mathrm{ha}-1 \mathrm{~mm}-1)$ and straw mulch (8.94 kg ha-1 mm-1) while, the minimum mean crop water productivity was observed on $55 \%$ ETc and no mulch (6.57 kg ha-1 mm-1). There was significant difference between $100 \%$ ETc SM and $85 \%$ ETc NM, $100 \%$ ETc NM and 55\% ETc PM and between, 70\% ETc $\mathrm{NM}$ and 55\% ETc SM at $(\mathrm{P}<0.05)$ (Table 6). The result of this study showed that, in the same water application level in the order of no mulch, straw and plastic mulch respectively resulted a conforming increase of crop water productivity.

From this result, it is seen that irrigation applied with $85 \%$ ETc under plastic mulch can increases the crop water productivity with lower yield reduction. Therefore, when water source is scarce, the onion can be irrigated at the lower water level (85\% ETc) under plastic mulch considering economic conditions.

\section{Yield Response Factors (Ky)}

The yield response factor (ky) was derived from the relationship of relative yield reduction $(1-\mathrm{Ya} / \mathrm{Ym})$ and relative evapotranspiration deficits (1-ETa/ETm) for the whole growing period of Onion. The result indicates that observed yield response factors (ky) for Nasik Red onion variety Bulb production ranged between 0.44 and 1.00. The lowest yield response factor (0.44) was observed under treatment received $85 \%$ ETc under plastic mulch whereas highest yield response factor (1.00) was observed under the treatment received 55\% ETc irrigation levels and control (no mulch). Allowing to this result deficit irrigations level, $85 \%$ ETc of the full irrigation under plastic mulch is therefore useful in saving irrigation water. The higher Ky values indicate that the crop will have a greater yield loss when the crop water requirements are not met. When joint values were used, a ky factor of 1.33 was obtained. Doorenbos and Kassam (1979) reported that Onion yield response factor (ky) would be greater than 1, which corresponded to ky of this study. Under conditions of limited water distributed equally over the total growing season, the crop with $(\mathrm{ky}>1)$ would suffer a greater yield loss than the crop with $(\mathrm{ky}<1)$. This shows that Onion is susceptible horticultural plant to drought stress.

\section{Conclusion}

The study was targeted at determining the water productivity of Onion (Allium cepa L.) under distinct levels of deficit irrigation practice and mulch types and the effects on yield of Onion during water stress without significant yield reduction. The experimental design was a split plot in RCBD arrangement with three replications.

The analysis of variance revealed that leaf number per plant was significantly affected $(\mathrm{P}<0.01)$ by the main effects of deficit irrigation levels and mulch types but not by the interaction effect of the two. This shows that recommendation of deficit irrigation and mulch type should be done distinctly for the parameter. Nevertheless, the interaction effects of deficit irrigation levels and mulch types significantly affected days to maturity, plant height, leaf height per plant, bulb diameter, marketable, unmarketable and total bulb yields of the onion.

There was highly significant difference on the crop water productivity due to the interaction effects of deficit irrigation levels and mulch types. The highest CWP of 9.08 $\mathrm{kg}$ ha-1 mm-1 was obtained from irrigation water application $85 \%$ ETc and plastic mulch while the lowest CWP of $6.57 \mathrm{~kg}$ ha-1 mm-1 was verified under $55 \%$ water deficit and no mulch. With $85 \%$ ETc and plastic mulch the water saved, yield reduction and CWP were $113.13 \mathrm{~mm}$, $9.57 \%$ and $9.08 \mathrm{~kg}$ ha- $1 \mathrm{~mm}-1$, respectively. In view of the highest water saved and maximum onion yield, irrigation water application at $85 \%$ irrigation application levels and plastic mulch could be considered as optimal irrigation management as compared to the rest of deficit treatment levels. Experimental yield response factors (ky) for Onion bulb production ranged between 0.44 and 1.00 , the lowest and highest being for $85 \%$ ETC water application level under straw mulch and 55\% ETc applications under no mulch, respectively.

In general, results from the current level of work deeprooted that there exists a relative delay in maturity, increased plant height, number of leafs per plant, marketable bulb yield, total bulb yield and higher water productivity due to decrease in deficit irrigation levels. These results confirmed that joining different irrigation levels with the use of mulch covers, chiefly straw mulch that is in plenty with growers or farmers, boons a sustainable strategy for onion production in the water shortage areas of Ethiopia. Usage of plastic mulches putting complications with these materials in windy conditions presents challenges to growers. Daunting irrigation deficit levels further than $55 \%$ is not necessary as marketable yields and bulb diameter decline. The furrow irrigation system used in the study is at entry level for farmers and it is apply demonstrated from the work that the volume of water savings that can be attained is significant when compared to other surface irrigation systems.

\section{Acknowledgement}

Authors are highly grateful to Post Graduate Program Directorate for granting the research fund. The authors also acknowledge Haramaya University on authorizing Soil Laboratory for chemical and physical analysis of experimental soil water.

\section{References}

Awulachew BD, Aster L, Makonnen L, Willibald A, Mekonnen A, Tena A. 2007. Water Resources and Irrigation Development in Ethiopia. International Water Management Institute. (Working Paper 123). Colombo, Sri Lanka. 
Allen R, Pereira LA, Raes D, Smith M. 1998. Crop evapotranspiration guidelines for computing crop water requirements. Irrigation and Drainage Paper No. 56. FAO, Rome.

Singh R, Kumar M, Smarandache F. 2010. Ratio estimators in simple random sampling when study variable is an attribute. World Applied Sciences Journal 11(5): 586-589.

Zwart SJ, Bastiaanssen WGM. 2004. Review of measured crop water productivity values for irrigated wheat, rice, cotton and maize. Journal of Agricultural Water Management, 69(2).

Lemma Dessalegn and Shemelis Aklilu 2003. Research results and experiences in onion dry bulb and seed production in Ethiopia. Vegetable crops improvement research, EARO, Melkassa Agricultural Research Centre. p39.

Bosland PW, Votava EJ. 2000. Pepper: Vegetable and Spice Capsicums. CABI Publishing, New York.

Chawla SL. 2006. Effect of irrigation regimes and mulching on vegetative growth, quality and yield of flowers of African marigold. Ph.D. Thesis, Department of Horticulture, Maharana Pratap University of Agriculture and Technology, Udaipur.

Randle WM. 2000. Increasing nitrogen concentration in hydroponic solutions affects onion flavour and bulb quality. Journal of the American Society for Horticultural Science, 125: 254-259.

Ray N, Yadav DS. 2005. Advances in vegetable production. Research book center. New Delhi. 237-238. Research, Vol. 78: p. 51-64.

Dirirsa G, Woldemichael A, Hordofa T. 2017. Effect of deficit irrigation at different growth stages on Onion (Allium cepa L.) production and water productivity at Melkassa, Central Rift valley of Ethiopia. Acad. Resource Journal Agriculture Science. Resource. 5(5): 358-365.

Heidari H. 2012. Alternate Furrow Irrigation Effect on Yield, Yield Components and Seed

Kadayifci AGI, Tuylu Y, Ucar B, Cakmak GI. 2004. Crop water use of onion (Allium cepa L.) in Turkey. Journal of Agricultural Water Management, 72:59-68.
Habtamu Gudisa M. 2017. Onion (Allium cepa L.) Yield Improvement Progress in Ethiopia: A Review. International Journal of Agriculture and Biosciences, 6(5): 265-271.

Patel N, Rajput TBS. 2013. Effect of deficit irrigation on crop growth, yield and quality of onion in subsurface drip irrigation. InternationalJournalof Plant Production, 7(3): 417-435. doi: 10.22069/ijpp.2013.1112.

Tasisa Temesgen, Mokenon Ayana and Bobe Bedadi 2018. Irrigation Level Management and Mulching on Onion (Allium cepa L.) Yield and WUE in Western Ethiopia.

Michael A. 2008. Irrigation theory and practice. Indian Agriculture Research Institute, New Delhi, India, 427-429.

Rop DK, Emmanuel C, Kipkorir K, John Taragon K. 2016. Effects of Deficit Irrigation on Yield and Quality of Onion Crop. Journal of Agricultural Science, 8(3): 1916-9760.

Mokenon Ayana 2011. Deficit irrigation practices as alternative means of improving water use efficiencies in irrigated agriculture: A study of maize crop at Arba Minch, Ethiopia. African Journal of Agricultural Research, 6(2): 226-235.

Nigatu AW. 2008. Identification of the critical water requiring growth stage on Onion (Allium cepa L.) for bulb production in the Central Rift Valley. MSc. Thesis. Haramaya University, Ethiopia.

Smith R. 2011. Fresh onion bulb production in California. Agricultural and Natural Resources Communication Service, 13: $987-10$

Temesgen T, Ayana M, Bedadi B. 2018. Evaluating the Effects of Deficit Irrigation on Yield and Water Productivity of Furrow Irrigated Onion (Allium cepa L.) in Ambo, Western Ethiopia. Journal of Irrigation Drainage System Engineering 7: 203

Tilahun H, Yusuf K, Mesfine M. 2004. Response of tomato to different irrigation schedules under Melkassa conditions. pp 202-203. 